\title{
OPINION 2/13 OF THE COURT OF JUSTICE OF THE EUROPEAN UNION: ANALYSIS AND FURTHER PERSPECTIVES OF EUROPEAN UNION ACCESSION TO THE EUROPEAN CONVENTION ON HUMAN RIGHTS
}

N. I. DAMINOVA, PhD candidate in european law, the Sant'Anna School of Advanced Studies (Scuola Superiore Sant'Anna), Institute of Law, Politics and Development (Instituto DIRPOLIS)

33, Piazza Martiri della Libertá, 56127, Pisa, Italy

E-mail: nasiya.daminova@sssup.it

This paper is devoted to the legal analysis of CJEU Opinion 2/13 on European Union accession to the European Convention on Human Rights. The article examines the CJEU's approach to the interpretation of Art. 267 and 344 of the Treaty on the Functioning of the European Union - in the light of Protocol No. 16 to the European Convention on Human Rights, as well as the previous case law of the Court of Justice (Mox Plant and Melki and Abdeli). The conclusions are drawn as to the manner in which Opinion 2/13 develops EU legal order autonomy doctrine and how it affects the future perspectives of EU accession to the European Convention on Human Rights. Firstly, while interpreting the content and purpose of Art. 344 TFEU, the CJEU gives a positive answer to the question as to whether the ECHR compliance system falls within the ambit of this Treaty provision. Secondly, the Court of Justice takes an extremely protective approach in giving its interpretation to the role of preliminary rulings procedure guaranteed by Art. 267 TFEU for the unity and efficiency of European law, making even the legal protection of individuals secondary to these purposes. It is quite probable that the accession will be delayed for an indefinite period of time - due to the likely impossibility of reaching a consensus on a new version of the Draft accession agreement with all members of the Council of Europe (such as Russia, Ukraine and Turkey) in the very near future. At the same time, European Union accession to the European Convention on Human Rights remains a legal duty in accordance with Art. 6 Treaty on the European Union (TEU), Declaration No. 2 on Article 6 (2) TEU and Protocol No. 8 to the Lisbon Treaty.

Keywords: EU accession to the ECHR, EU legal order autonomy doctrine, Opinion 2/13, Art. 267 TFEU, Art. 344 TFEU, Protocol No. 16 ECHR.

\section{МНЕНИЕ 2/13 СУДА ЕВРОПЕЙСКОГО СОЮЗА: АНАЛИЗ И ДАЛЬНЕЙШИЕ ПЕРСПЕКТИВЫ ПРИСОЕДИНЕНИЯ ЕВРОПЕЙСКОГО СОЮЗА К ЕВРОПЕЙСКОЙ КОНВЕНЦИИ ПО ПРАВАМ ЧЕЛОВЕКА}

\author{
ДАМИНОВА Насия Ильдаровна, Высшая школа перспективных исследований им. Святой Анны \\ Италия, 56127, г. Пиза, пл. Мартири-делла-Либерта, 33 \\ E-mail: nasiya.daminova@sssup.it
}

Статья посвящена правовому анализу мнения Суда EC 2/13 (оріnion 2/13) о Договоре о присоединении Европейского Союза (ЕС) к Европейской конвенции по правам человека (ЕКПЧ). Рассматривается подход Суда ЕС к толкованию статей 267 и 344 Договора о функционировании ЕС (ДФЕС) в свете Протокола № 16 к ЕКПЧ, а также предыдущих прецедентов Суда EC (Mox Plant и Melki and Abdeli). Делаются выводы о том, как мнение 2/13 способствует развитию доктрины автономии правопорядка ЕС и может повлиять на дальнейшие перспективы присоединения Европейского Союза к ЕКПЧ. Во-первых, при интерпретации содержания и цели статьи 344 ДФЕС Суд ЕС включает контрольную систему Совета Европы в сферу действия данного положения Договора. Во-вторых, Суд разъясняет смысл нормы статьи 267 ДФЕС, провозглашая процедуру предварительного решения по делу основой обеспечения единства и эффективности европейского права и делая даже защиту прав фризческих лиц вторичной по отношению к этим целям. Предположительно присоединение Европейского Союза к ЕКПЧ будет отложено на неопределенный срок в связи с вероятной невозможностью достижения согласия со всеми членами Совета Европы (такими, как Россия, Украина и Турция) в ближайшем будущем относительно новой версии Договора о присоединении. В то же время присоединение ЕС к ЕКПЧ остается юридической обязанностью в соответствии со ст. 6 Договора о Европейском Союзе (ДЕС), Декларацией № 2 к статье 6 (2) ДЕС и Протоколом № 8 к Лиссабонскому договору.

Ключевые слова: присоединение Европейского Союза к Европейской конвенции по правам человека, доктрина автономии европейского правопорядка, мнение 2/13 Суда ЕС, ст. 267 ДФЕС, ст. 344 ДФЕС, Протокол № 16 к ЕКПЧ.

DOI: $10.12737 / 17170$ 
1. Introduction. The discussion on the ways to achieve the accession of the European Union (hereafter EU) to the European Convention on Human Rights (hereafter ECHR) had taken place within both organizations in the late $1970 \mathrm{~s}^{1}$, before the issue was brought to the forefront once again with the adoption of the European Union Charter of Fundamental Rights (7 December 2000). With the entry into force of the Lisbon Treaty (1 December 2009) and of Protocol No. 14 ECHR (1 June 2010) it became a legal obligation. The Lisbon Treaty, with its two complementary achievements of a legally binding character of the EU Charter of Fundamental Rights (further - the Charter) and a commitment by the EU to accede to the ECHR, marked a major step forward towards a stronger and more coherent system of fundamental rights protection. Art. 6 (2) of the Treaty on the European Union (further TEU) now stipulates an obligation for the Union to accede to the Convention under the condition that the agreement relating to the accession makes provisions for preserving the specific characteristics of the Union and Union law.

The "specificity" was summarized by the Lisbon Treaty, Protocol No. 8 to the Lisbon Treaty and CJEU case-law as follows: an external autonomy, supranational character, as well as the monopoly of the Court of Justice to decide on the distribution of competences between the EU and its Member States, and to interpret and review the legality of EU acts². The Final Draft accession agreement of 5 April 2013 met (mainly) a positive response among most leading scholars and practitioners as the legal constructs offered seemed to be consistent with these specifications ${ }^{3}$ — thanks

${ }^{1} \mathrm{CDDH}(2011) 009$, Report to the Committee of Ministers on the elaboration of legal instruments for the accession of the European Union to the European Convention on Human Rights. See also Erich Stauder v City of Ulm - Sozialamt, Case 29-69, Judgment of the CJEU of 12 November 1969; InternationaleHandelsgesellsc haftmbHv Einfuhr-und VorratsstellefürGetreide und Futtermittel, Case 11-70, Judgment of the CJEU of 17 December 1970; Nold, Kohlen- und Baustoffgroßhandlung $v$ Commission of the European Communities, Case 4-73, Judgment of the CJEU of 14 May 1974; Roland Rutili v Ministre de l'intérieur, Case 36-75, Judgment of the CJEU of 28 October 1975; LiselotteHauer $v$ Land RheinlandPfalz, Case 44/79, Judgment of the CJEU of 13 December 1979.

2 See, for example, Opinion 1/91, Re Draft agreement between the Community, on the one hand, and the countries of the European Free Trade Association, on the other, relating to the creation of the European Economic Area [1991] ECR I-6079; Opinion 2/94, Re Accession by the Communities to the Convention for the Protection of Human Rights and Fundamental Freedoms [1996] ECR I-1759; Opinion 1/00, Re Agreement between the European Community and non-Member States on the establishment of a European Common Aviation Area [2002] ECR I-3493.

${ }^{3}$ See, for example, Roberto Baratta, "Accession of the EU to the ECHR: The rationale for the ECJ's prior involvement mechanism" (2013) 50 Common Market Law Review (Issue 5) 1305-1332 1311; Jörg Polakiewicz, "EU Law and the ECHR: Will EU Accession to the European Convention on Human Rights Square the Circle?" to the creation of a co-respondent mechanism in cases involving both the EU and one or more of its Member States (Article 3 of the Draft) and the new possibility of prior involvement of the CJEU in procedures where the EU Law provisions are invoked (Article 3 (6) of the Draft).

In the light of these innovations, Opinion $2 / 13$, released on 18 December 2014, came as a very great surprise for almost everyone dealing with European law matters. In fact, the answer of the CJEU was negative as the Draft accession agreement failed to take into account the specific characteristics of EU law with regard to the judicial review of acts, actions or omissions on the part of the EU in Common Foreign and Security Policy (further - CFSP) matters.

In my perception, one of the reasons for this approach was the development of the EU legal order autonomy doctrine by CJEU Opinion 2/13, which I would like to explore in the present paper. I believe that the most crucial changes are connected with the Court's interpretation of Arts. 267 and 344 of the Treaty on the Functioning of the European Union (TFEU) in relation to Protocol No. 16 to the European Convention on Human Rights (hereinafterProtocol No. 16 ECHR). I would like to focus on these theoretical developments to compare them with the previous case-law of the CJEU, as well as to trace their influence on the future perspectives of Union accession to the ECHR. This paper is structured as follows: Part 2 is devoted to the analysis of the content of Advocate General Juliane Kokott's view and Opinion 2/13, Part 3 - to the Court's interpretation of Art. 344 TFEU and Protocol 16 ECHR, Part 4 - presents my conclusions on the future of European Union accession to the ECHR in the light of this evolution of EU legal order autonomy. I do not claim to fully describe and analyze all aspects of EU legal order autonomy touched upon by Opinion 2/13, but rather to focus on the most important (and inter-related) changes brought about by the Court's analysis of Arts. 344 and 267 TFEU in the light of the Protocol No. 16 ECHR provisions.

2. The CJEU's legal reasoning in Opinion 2/13. To start with, it is necessary to highlight Advocate General Kokott's View. Madame Kokott makes focusses on the inviolability of EU competences, the powers of the EU institutions, necessary arrangements for the participation of the EU in the control bodies of the ECHR and the situation of Member States in relation to the ECHR ${ }^{4}$

(SSRN, September 26, 2013) <http://ssrn.com/abstract=2331497> 12; Paul Gragl, "A giant leap for European Human Rights? The Final Agreement on the European Union's accession to the European Convention on Human Rights“ (2014) 51 Common Market Law Review (Issue 1) 13-58 16.

${ }^{4}$ Opinion 2/13, Re Accession of European Union to the Convention for the Protection of Human Rights and Fundamental Freedoms [2014] Opinion of the Court (Full Court) of 18 December 2014 (nyr), View of Advocate general Kokott delivered on 13 June 2014, Opinion procedure 2/13 initiated following a request made by the European Commission, para. 31. 
and concludes that the Draft accession agreement is consistent with EU primary law and admissible for CJEU consideration.

The CJEU commences its Opinion with a brief analysis of the EU institutional framework enabling EU accession, the current relationship between the EU and the $\mathrm{ECHR}^{6}$, as well as the process of accession? ${ }^{7}$. Then, the judges give a brief overview of the Draft accession agreement provisions $^{8}$, the Commission's assessment in its request for an Opinion and summarize the main observations of EU Member States, the Parliament and the Council submitted to the Court of Justice ${ }^{9}$. The Member States and institutions involved conclude, in essence, that the draft agreement is compatible with the Treaties, and largely endorse the Commission's assessment - although the reasoning is quite different from that of the Commission in a number of aspects ${ }^{10}$.

The most interesting part of Opinion $2 / 13$ is quite evidently the position of the Court which starts the legal assessment from the question of admissibility. The judges mainly follow the logic of Advocate General Kokott supporting two main arguments: firstly, the judges have sufficient information on the actual content of the Draft accession agreement as the Commission has submitted the full text of the draft agreement and its accompanying documents to the Court ${ }^{11}$. Secondly, the precise configuration of any internal implementing measures at EU level or the agreement between the member States on their precise form cannot influence the admissibility of the request for an Opinion ${ }^{12}$. On the basis of these premises, the Court of Justice finds a Commission request for the Opinion on the Draft accession instruments admissible - this conclusion was rather predictable.

${ }^{5}$ Opinion 2/13, Re Accession of European Union to the Convention for the Protection of Human Rights and Fundamental Freedoms [2014] Opinion of the Court (Full Court) of 18 December 2014 (nyr), paras. 3-36.

${ }^{6}$ Ibid., paras. 37-45.

${ }^{7}$ Ibid., paras. $46-48$.

${ }^{8}$ Ibid., paras. $49-57$.

${ }^{9}$ Ibid., paras. $71-143$.

${ }^{10}$ The main points of the Member States critique were, for example, the possibility for the CJEU to assess the internal rules implementing the Draft accession agreement within the EU legal order in line with the text of the Draft text (Polish and Swedish Governments), distribution of responsibility between the co-respondents for the ECHR violations by the ECtHR (Austrian Government), the accession to the Protocols to the ECHR (Slovak Government), as well as the possible extension of the CJEU jurisdiction in the CFSP matters (the United Kingdom Government).

${ }^{11}$ Opinion 2/13, Re Accession of European Union to the Convention for the Protection of Human Rights and Fundamental Freedoms [2014] Opinion of the Court (Full Court) of 18 December 2014 (nyr), paras. 144-148.

${ }^{12}$ Ibid., paras. $149-152$.
The Court of Justice also makes several preliminary remarks on the crucial importance of Art. 6 of the TEU of the Lisbon Treaty, Protocol No. 8 EU and Declaration on Article 6 (2) of the Treaty on the European Union. On the one hand, these provisions create an obligation for the EU to accede to the ECHR for the first time in the history of EU Law; on the other hand, they preclude the EU from being treated as a state and therefore require that such accession does not affect the specific characteristics of the EU and EU law. The Court emphasizes a special role of preliminary reference procedure as a "keystone" of the EU judicial system serving to ensure its consistency, full effect, autonomy and the particular nature of EU primary law as such.

Interestingly, the substantive part of Opinion 2/13 reflected almost all previous concerns which were previously expressed in the literature: a threat to the external and internal autonomy of EU legal order ${ }^{13}$, as well as the related issues of indirect review of primary or secondary EU law by the Strasbourg Court without having the jurisdiction to do $\mathrm{so}^{14}$, possible violation of EU powers in the area of freedom, security and justice ${ }^{15}$, a threat to the exclusive competence of the CJEU with regard to the disputes between EU Member States, and those between EU Member States and EU institutions ${ }^{16}$. The CJEU gives the following reasons for finding the Draft accession agreement incompatible with EU primary law provisions:

a) specific characteristics and the autonomy of EU law are not sufficiently protected. This viewpoint of the CJEU was quite unexpected - considering the quite positive assessment of specific arrangements for ensuring the autonomy of EU legal order in the draft agreement (i. e. Articles 1 and 3 of the Draft agreement on co-respondent and prior involvement procedures) made by AG Kokott ${ }^{17}$.

Firstly, the CJEU points out that the Draft accession agreement does not solve the contradictions between Art. 53 of the ECHR which allows Contracting Parties to establish higher standards of protection of fundamental rights than those guaranteed by the

${ }^{13}$ Tobias Lock, "Walking on a tightrope: the draft ECHR agreement and the autonomy of the EU legal order" (2011) 48 Common Market Law Review (Issue 4) 1025-1054 1025.

${ }^{14}$ Tobias Lock, "The ECJ and the ECtHR: The Future Relationship between the Two European Courts" (2009) 8 Law and Practice of International Courts and Tribunals 375-398 376.

${ }^{15}$ Jean-Paul Jacqué, "The Accession of the European Union to the European Convention on Human Rights and Fundamental Freedoms" (2011) 48 Common Market Law Review 95-1023 9951001.

${ }^{16}$ Roberto Baratta, "Accession of the EU to the ECHR: The rationale for the ECJ's prior involvement mechanism" (2013) 50 Common Market Law Review (Issue 5) 1305-1332 1311.

${ }^{17}$ Opinion 2/13, Re Accession of European Union to the Convention for the Protection of Human Rights and Fundamental Freedoms [2014] Opinion of the Court (Full Court) of 18 December 2014 (nyr), View of Advocate General Kokott, paras. 172 - 195. 
Convention provisions - and Art. 53 of the Charter of Fundamental Rights and the corresponding CJEU case-law (recent Melloni judgment) ${ }^{18}$ which prohibit a higher level of the guarantees in the areas where the EU legislation is fully harmonized. Therefore, the provisions of Art. 3 (6) of the Draft accession agreement may lead to the situation where the European Court of Human Rights (hereinafter - ECtHR) is forced to decide on the scope ratione materiae of EU law and therefore violate the interpretative monopoly of the CJEU. Secondly, the CJEU finds that the Draft Accession agreement does not provide necessary provisions to apply the principle of mutual trust in Justice and Home Affairs matters between the Member States - as EU Member States will be forced to check the level of human rights guarantees in the other ECHR state parties, including the EU States - although this power transferred to the Union will undermine the balance of EU competences. Thirdly, the CJEU expresses the concern that Protocol 16 to the ECHR may influence the effectiveness of the preliminary ruling procedure guaranteed by Art. 267 TFEU. This issue will be discussed in greater detail in Part 3 of this paper;

b) draft accession agreement provisions are inconsistent with Art. 344 TFEU.

The CJEU stresses that the monopoly of the CJEU on the interpretation of EU law and the inviolability of the competences allocation fixed by the Treaties are the conditions for the adoption of international agreements. In this part of the judgment, the Court is defending its monopoly on dispute settlement in the inter-state cases which may be compromised by ECtHR jurisdiction Part 3 is an analysis of the CJEU interpretation of Art. 344 content;

c) draft provisions on the co-respondent mechanism are not compatible with EU law. Firstly, the Court points out that the possible involvement of the Contracting Party (including the EU) as co-respondent is possible via accepting an invitation (which is not binding) from the ECtHR or by (binding) decision of the ECtHR upon the request of that Contracting Party. If the invitation procedure is not likely to violate EU Law concerning the distribution of competences, the request procedure of the Draft agreement may be a threat in this regard as it would give the ECtHR the power to interpret EU law when assessing the admissibility of requests to invoke a co-respondent procedure. Secondly, the CJEU criticizes the provisions of Art. 3 (7) of the draft Accession agreement regarding the joint responsibility of the respondent and co-respondent for the ECHR violation. Such provisions may create a situation where the EU Member State as a respondent or co-respondent may be considered responsible for the violation of the ECHR provision(-s) in respect of which that Member State may

${ }^{18}$ Case C-399/11, Melloni v Ministerio Fiscal [2013] Judgment of the Court (Grand Chamber) of 26 February 2013 (nyr). have made a reservation in accordance with Article 57 of the ECHR. Thirdly, the Court finds another problematic provision in the content of Art. 3 (7) of the Draft Accession Agreement on the distribution of responsibility between the respondent and co-respondent. It is not stated directly in the Draft accession agreement and the explanatory report that the reasons of the respondent and co-respondent shall be prepared jointly (and the position of the EU and the Member State are therefore in agreement), which may affect the inviolability of the competences division established by the EU Treaties. At the same time, even if the agreement in these kinds of statements of the respondent and co-respondent is presumed, the question of the apportionment of responsibility must be resolved solely in accordance with the relevant rules of EU law and fall within the CJEU's exclusive jurisdiction;

d) the prior involvement procedure may undermine the CJEU's interpretative autonomy. The CJEU emphasizes again that the prior involvement procedure (as a part of the co-respondent mechanism) is created to protect EU legal order autonomy as required by Article 2 of Protocol No. 8 EU. However, Art. 3 (6) of the draft accession agreement and the Explanatory report does not exclude the situation where the question of law which has already been scrutinized and interpreted by the CJEU may become an issue in the proceedings before the ECtHR. Under such circumstances, the permission for the ECtHR to rule on such a question would be equivalent to conferring on it a jurisdiction to interpret the existing case-law of the Court of Justice;

e) possible transfer of the jurisdiction in CFSP matters to the ECtHR. In accordance with Art. 24 (1) of the Treaty on the European Union, the Court of Justice lacks jurisdiction regarding most Common Foreign and Security Policy matters - as the adoption of legislative acts is excluded and the European Parliament and of the Commission have a specific coordinating role in this area. At the same time, the Draft accession agreement defines the scope of the ECtHR judicial review in this area as being sufficiently broad to encompass almost any situation in the area of CFSP. On the basis of accession as provided for by the agreement envisaged, the ECtHR would be empowered to rule on the compatibility with the ECHR of certain acts, actions or omissions performed withinthe context of the CFSP, and notably of those whose legality the Court of Justice cannot, for lack of jurisdiction, review in the light of fundamental rights. From the point of view of the CJEU, such a situation would mean a transfer of the judicial review of EU acts, actions or omissions exclusively to a non-EU body, even if that review would be limited to compliance with the rights guaranteed by the ECHR.

3. Arts. 267 and 344 TFEU in the light of Protocol No. 16 ECHR. It is self-evident that the issue of the possibility of external control of the ECtHR over EU institutions (including the CJEU itself) was the most controversial issue even before the accession and gave 
rise to lively academic debate ${ }^{19} /$ Art. 19 (1) TEU defines a special role of the CJEU within EU legal order as only an interpreter of EU Treaties and an observer regarding their application within national legal systems. Arts. 267 TFEU and 344 TFEU create the legal framework for the functioning of the independent legal system of the European Union and reaffirm the role of the Union Courts in general: the former confers upon each national court an "autonomous jurisdiction" to make a reference to the CJEU and constitutes "the foremost institutional expression of the national courts" role in EU legal order and their collaboration with the $\mathrm{CJEU}^{20}$, while the latter precludes the EU Member States from submitting a dispute concerning the interpretation or application of Union Treaties to any method of settlement "other than those provided for therein". Moreover, Art. 3 of the Protocol No. 8 EU especially emphasizes that nothing in the Draft accession agreement shall affect the content of Art. 344 TFEU, i. e. the exclusive jurisdiction of the CJEU in solving inter-state cases. In the light of the provisions described above, two of the CJEU's arguments expressed in Opinion 2/13 deserve special attention, in particular the notion of Arts. 267 and 344 TFEU in the light of Protocol No. 16 ECHR, as the content of the latter is directly connected with the status of the preliminary references procedure within EU legal order.

3.1. An interpretation of Art. 344 TFEU by Opinion 2/13. Paras. $201-214$ of Opinion $2 / 13$ are devoted to the influence of EU accession on Art. 344 TFEU on the basis of the Draft accession agreement of 5 April 2013. The CJEU stresses that the monopoly of the CJEU on the interpretation of EU law and the inviolability of the competences allocation fixed by the Treaties are the conditions for the adoption of international agreements (this statement reppeals the earlier CJEU findings in Opinions $1 / 91^{21}$ and $1 / 00^{22}$ ).CJEU monopoly on dispute

19 See, for example, Christina Eckes, "EU Accession to the ECHR: Between Autonomy and Adaptation" (2013) 76 The Modern Law Review (Issue 2) 254-285; Jörg Polakiewicz, "EU Law and the ECHR: Will EU Accession to the European Convention on Human Rights Square the Circle?" (SSRN, September 26, 2013) <http:// ssrn.com/abstract=2331497>; José Martín Pérez de Nanclares, “The accession of the European Union to the ECHR: More than just a legal issue" (2013) IDEIR working paper No. $15<$ https://www.ucm. es/data/cont/docs/595-2013-11-07-the\%20accesion.pdf $>$.

${ }^{20}$ Allan Rosas, "Constitutionalising the EU Judicial System: Essays in Honour of Pernilla Lindh" (Pascal Cardonnel, Allan Rosas, Nils Wahl ed., Bloomsbury Publishing, 2012) 106.

${ }^{21}$ Opinion 1/91, Re Draft agreement between the Community, on the one hand, and the countries of the European Free Trade Association, on the other, relating to the creation of the European Economic Area [1991] ECR I-6079.

${ }^{22}$ Opinion 1/00, Re Agreement between the European Community and non-Member States on the establishment of a European Common Aviation Area [2002] ECR I-3493. settlement between Member States on the basis of the EU law is regarded as the main guarantee of the external autonomy of the EU legal order. Despite this, Art. 5 of the Draft agreement allows for the possibility that the EU or Member States might submit an application to the ECtHR, under Article 33 of the ECHR, concerning an alleged violation by a Member State or the EU, respectively, even in conjunction with EU law. Art. 5 of the Draft Agreement merely reduces the scope of the obligation laid down by Art. 55 of the ECHR while distinguishing the proceedings before the CJEU from the procedures of international investigation or dispute settlement within the Strasbourg system. However, from the point of view of the CJEU, only the fact that Member States or the EU are able to submit an application of this type to the ECtHR may undermine the objective of Article 344 TFEU and, moreover, goes against the very nature of EU law ${ }^{23}$.

Interestingly, the CJEU directly refers to the Commission v. Ireland ("Mox Plant") case starting the discussion on Art. 344 TFEU ${ }^{24}$. Indeed, the logic of Opinion 2/13 follows the Mox Plant line of reasoning, in which the CJEU acts in an especially jealous way to protect the uniformity of EU law in inter-state cases - while precluding Member States from initiating proceedings to any other court for the settlement of disputes within the scope of EU law. Paul Gragl expressed quite an interesting point of view on the future development of CJEU jurisdiction after EU accession to the ECHR in the light of this case: “...under Art. 19 (1) TEU, the CJEU will have the corresponding jurisdiction to interpret and apply the provisions of the Convention (in inter-state cases involving interpretation of corresponding provisions of the Charter of Fundamental Rights of the EU - author's note). This jurisdiction, most importantly, is exclusive as the Member States are prohibited under Art. 344 TFEU from submitting a dispute to any method of settlement other than provided for therein"25.

As a principle, Art. 3 of Protocol No. 8 and the Explanatory report to the draft accession agreement do not expressly contradict this point of view, ${ }^{26}$ but one can see that the CJEU has ignored these arguments for some reason. The Court of Justice also does not touch

${ }^{23}$ Opinion 2/13, Re Accession of European Union to the Convention for the Protection of Human Rights and Fundamental Freedoms [2014] Opinion of the Court (Full Court) of 18 December 2014 (nyr), para. 208.

${ }^{24}$ Ibid., para. 201.

${ }^{25}$ Paul Gragl, "Human Rights Law in Europe: The Influence, Overlaps and Contradictions of the EU and the ECHR" (Kanstantsin Dzehtsiarou, Theodore Konstadinides, Tobias Lock ed., Routledge Research in Human Rights Law) 37.

${ }^{26}$ Draft Explanatory report to the Agreement on the Accession of the European Union to the Convention for the Protection of Human Rights and Fundamental Freedoms (COE, 2 April 2013) $<$ http://www.coe.int/t/dghl/standardsetting/hrpolicy/Accession/ Working_documents/47_1(2013)007_EN.pdf>, para. 64-66. 
upon the argument of the Mox Plant judgment regarding the principle of sincere and loyal cooperation enshrined by Art. 4 (3) TEU, which also prohibits the application to non-EU Treaty bodies in inter-state cases. This was possibly because the Court was trying to avoid an interpretation of the corresponding provision of Art. 4 (2) TEU precluding the EU legislator and institutions from the disproportionate interferences, especially interferences in the essential core of national constitutions (especially in the light of the ECHR provisions), and in this case the discussion on the essence of the autonomy of EU legal order could go too far.

Nevertheless, Opinion 2/13 supports and develops the Mox Plant line of reasoning in one more important way. In Mox Plant, the Court of Justice found that Ireland was in breach of the obligation "not to submit a dispute concerning the interpretation of the Treaties to any method of settlement other than those provided for therein" and that Member States would be in breach of the duty of loyal cooperation by bringing proceedings before a dispute settlement body other than the Court of Justice, such as an arbitral tribunal, without first informing and consulting the competent Union institutions ${ }^{27}$. Nevertheless, the vague wording of Art. 344 and its interpretation in Mox Plant does not give a precise answer to the question as to whether the expressions "a dispute" and "any method of settlement" may include the ECHR compliance mechanism. In Opinion 2/13, the Court of Justice gives an answer to these questions. The Court states that "the disputes (a) between Member States or between Member States and the EU (b) in relation to the application of the ECHR within the scope ratione materiae of EU law" shall be directly excluded from the ECtHR's jurisdiction under Article 33 of the ECHR to make the next Draft accession agreement compatible with Art. 344 TFEU. Keeping in mind that the earlier CJEU interpretation of the word "Treaties" for the purposes of Art. 344 TFEU not only refers to primary EU Law, but also encompasses secondary EU legislation and international agreements concluded by the $\mathrm{EU}^{28}$, one can see that the Mox Plant approach was given a much broader interpretation in the Opinion in order to justify the skepticism of the CJEU towards the accession.

3.2. Potential effects of Protocol No. 16 ECHR on preliminary rulings procedure before the CJEU (Art. 267 TFEU). The second aspect of EU legal order autonomy touched upon by the CJEU is the potential effects of Protocol No. 16 ECHR which allows the highest courts and tribunals of the States Parties to request the ECtHR to give advisory opinions on questions relating to the

27 Elisa Morgera, "The External Environmental Policy of the European Union: EU and International Law Perspectives" (Cambridge University Press, 2012) 303.

${ }^{28}$ Case C-61/94, Commission of the European Communities $v$ Federal Republic of Germany [1996] ECR I-3989, para. 52. interpretation of Convention rights. The CJEU reveals this issue as the third argument in the part of Opinion 2/13 devoted to the specific characteristics and the autonomy of EU law. While two first arguments on the prohibition of external control over EU institutions and the notion of mutual trust in Justice and Home Affairs matters are quite predictable, the critique on Protocol 16 ECHR appears quite unexpected. One should remember that this Protocol was optional for the signature of the Council of Europe Member States, and the Draft accession agreement did not envisage the EU joining that Protocol in the course of accession. This is why it was not previously considered relevant for the proceedings ${ }^{29}$. Moreover, the work on the final Draft accession agreement of 5 April 2013 and Protocol 16 ECHR took place in the same period of time, and some authors even saw it as one of the means for accommodating the co-respondent mechanism within EU legal order ${ }^{30}$.

The CJEU legal reasoning of this part of judgment expresses the concern that Protocol No. 16 ECHR may undermine the effectiveness of the preliminary ruling procedure guaranteed by Art. 267 TFEU. In accordance with Art. 1 of Protocol No. 16, "the highest courts and tribunals of a High Contracting Party... may request the Court to give advisory opinions on questions of principle relating to the interpretation or application of the rights and freedoms defined in the Convention or the protocols thereto" ${ }^{31}$. At the same time, Art. 267 (3) TFEU obliges the same courts (i. e. "a court or tribunal of a Member State against whose decisions there is no judicial remedy under national law") to bring the matter before the Court of Justice of the European Union. As a result, the supreme courts or tribunals of the EU Member States will be allowed to submit the questions concerning, for example, the interpretation of rights guaranteed by the Charter corresponding to those secured by the ECHR to the ECtHR instead of to the CJEU. The Draft accession agreement does not include any provisions in respect of the relationship between the mechanism established by Protocol No. 16 and the preliminary ruling procedure provided for in Article 267 TFEU, which (at least in the eyes of the CJEU judges) makes Protocol 16 to the ECHR a threat to the external autonomy of EU legal order. This

${ }^{29}$ For a comment on the hearing of May 2014 at the ECJ concerning this opinion, see: Stian Oby Johansen, "Some thoughts on the CJEU hearing on the Draft EU - ECHR Accession Agreement. Part 1 of 2" (Øby-kanalen, 6 May 2014) <https:// obykanalen.wordpress.com/2014/05/06/some-thoughts-on-the-ecjhearing-on-the-draft-eu-echr-accession-agreement-part-1-of-2>.

${ }^{30}$ Theodore Konstadinides and Noreen O'Meara, "EU Security and Justice Law: After Lisbon and Stockholm" (Diego Acosta Arcarazo, Cian Murphy ed, Bloomsbury Publishing, 2014) 82.

${ }^{31}$ Protocol No. 16 to the Convention for the Protection of Human Rights and Fundamental Freedoms CETS No. 214 (ECHR COE, 2 October 2013) <http://www.echr.coe.int/Documents/ Protocol_16_ENG.pdf $>$. 
approach of the Court quite evidently demonstrated the awareness of the interpretative competition between the European Courts and the risk of conflicts after accession $^{32}$.

Surprisingly, the CJEU connected the influence of Protocol No. 16 ECHR to two fundamental theoretical issues - the importance of the preliminary reference procedure as an integral part of the EU judicial system and its role in the protection of primacy EU Law within the legal order of the EU. The position of the CJEU expressed in Opinion 2/13 seems to illustrate the development of the previous lines of reasoning in Melki and Abdeli $\operatorname{case}^{33}$. This case deals with the goals and the role of the preliminary reference procedure for EU law development. In the Melki and Abdeli case, involving a reference for the preliminary ruling from the French Court of cassation (Cour de Cassation) as to whether a provision of French constitutional law, requiring national courts to rule, as a matter of priority, on the submission to the French Constitutional Council (Conseil Constitutionnel) of questions constitutionality put before them, was compatible with Art. 267 TFEU. The Court of Justice provided a balanced answer, stating that the national courts cannot be prevented from referring questions to the Court, and therefore, if an interlocutory procedure giving priority to the review of constitutionality of national law effectively prevents these courts from referring questions to the Court, such a procedure shall be prohibited under Art. 267 TFEU. In Melki, the CJEU proclaims the special importance of Art. 267 TFEU stating that national courts shall remain free to submit a reference for a preliminary ruling to the Court, at whatever stage of proceedings they consider appropriate, on any question they consider necessary ${ }^{34}$.

In Opinion 2/13, the Court goes even further, describing the preliminary reference procedure as the "the keystone of the judicial system established by the Treaties". It will be affected if no special provisions are made to balance the relationship between Protocol 16 ECHR and the preliminary ruling procedure of Art. 267 TFEU, as it will affect the autonomy and effectiveness of the latter procedure $^{35}$. Moreover, in Opinion the Court supports the Melki line of reasoning, ruling that the primary purpose and objective of the preliminary ruling procedure is to guarantee the primacy, uniformity and effectiveness of European Union law, making the legal protection of

${ }^{32}$ Giuseppe Martinico, "Four Points on the Court of Justice of the EU. Perspectives on Federalism" (2014) 6 Perspectives on Federalism (Issue 3) 102-125 114.

${ }^{33}$ Joined cases of C-188/10 and C-189/10, Aziz Melki and Sélim Abdeli [2010] ECR I-5667.

${ }^{34}$ Ibid., para. 57.

${ }^{35}$ Opinion 2/13, Re Accession of European Union to the Convention for the Protection of Human Rights and Fundamental Freedoms [2014] Opinion of the Court (Full Court) of 18 December 2014 (nyr), para. 197-199. individuals merely secondary to this goal ${ }^{36}$ - which can appear quite amusing within the context of the accession to one the basic Human Rights Law treaties. In my perception, Opinion 2/13 may be considered a milestone in the discussion on "re-positioning the Strasbourg Court" in the light of EU accession to the ECHR and the ongoing reform of the Convention system. It is quite likely that this approach of the CJEU will be continued in its future jurisprudence protecting the Union legal order from the Strasbourg Court interventions, and therefore the role of the ECtHR will become less influential, at least for the 28 Member States of the European Union. This kind of dual membership in two international bodies, i. e. the Council of Europe and European Union at the same time may be a reason for further constitutional conflicts in the future (caused, for example, by the ratification of Protocol No. 16 ECHR by the EU Member State).

4. Conclusions. First and foremost, the accession on the basis of the Draft accession agreement from 5 April 2013 seems no longer possible in the light of CJEU Opinion $2 / 13$, although some scholars support an opposite point of view ${ }^{37}$. The CJEU's approach looks quite formalistic and the Court was reluctant to accept most arguments given by the Advocate General, the Commission and Member States. The fact that the CJEU elaborates on the importance of EU legal order protection rather than on the effectiveness of the legal protection for individuals in the Opinion of this kind - also appears quite strange at first glance. As a principle, the CJEU emphasizes the importance of the Convention rights having a "fair trial" and "an effective remedy" only in the second part of Opinion 2/13 — while discussing the institutional framework and the procedural provisions on the conclusion of the accession agreement. Nevertheless, CJEU Opinion 2/13 made several important steps towards the development of the EU legal order autonomy doctrine - which maybe was the main purpose of the CJEU judges in the present proceedings.

Firstly, while interpreting the content and purpose of Art. 344 TFEU, the CJEU gives a final answer to the question as to whether the ECHR compliance system falls within the ambit of this Treaty provision. The CJEU finally includes the Strasburg court in the phrase "any method of settlement" and clarifies that the expression "a dispute" for the purposes of Art. 344 TFEU shall mean "the dispute (a) between Member States or

${ }^{36}$ Joined cases of C-188/10 and C-189/10, Aziz Melki and Sélim Abdeli [2010] ECR I-5667, para. 43; Opinion 2/13, Re Accession of European Union to the Convention for the Protection of Human Rights and Fundamental Freedoms [2014] Opinion of the Court (Full Court) of 18 December 2014 (nyr), paras. 197-198.

${ }^{37}$ See, for example, Leonard Besselink, "Acceding to the ECHR notwithstanding the Court of Justice Opinion 2/13" (Verfassungsblog, 23 December 2014), <http://www. verfassungsblog.de/en/acceding-echr-notwithstanding-courtjustice-opinion-213/\#.VVyCTizDQ-Q>. 
between Member States and the EU (b) in relation to the application of the ECHR within the scope ratione materiae of EU law". This approach at least clarifies the main point of academic debate taking place during negotiations for the previous versions of Draft accession agreements, but also makes the EU accession extremely problematic from the technical point of view (maybe even revision of Art. 33 of the European Convention?). At the same time, we can also expect that the CJEU may continue this line of reasoning, including other international courts in the scope of Art. 344 TFEU, and therefore restricting Member States to selecting only an EU dispute settlement system.

Secondly, the Court of Justice takes an extremely protective approach in giving its interpretation to the role of preliminary rulings procedure guaranteed by Art. 267 TFEU in the light of Protocol No. 16 ECHR. The Court continued the Melki line of reasoning by emphasizing the importance of preliminary references for the unity and efficiency of European Law, making even the legal protection of individuals secondary to these purposes. Moreover, Opinion 2/13 may be considered a manifestation of European Law primacy even in the area of human rights protection - it may be considered a step back from the virtue of Article 52 (3) of the Charter of Fundamental Rights, by which EU law has previously limited the scope of its autonomy, namely as regards those rights which the Charter has borrowed directly from the Convention.

As for the future perspectives of European Union accession to the ECHR, it is possible to claim that the CJEU's negative decision and therefore the postponement of accession may be a wise and even unavoidable political move under current circumstances, i. e. the influence of the financial crisis on the economies of several Member States as well as current tensions between the Council of Europe State Parties. Even the controversial situation where Opinion 2/13 de facto precludes the EU Member States from joining Protocol No. 16 ECHR may not necessarily be seen as negative. By stating this, the Court of Justice excluded the possibility for the supreme courts of the EU Member States to ask for the advisory opinion of the ECtHR after the previous national court has already been given the CJEU preliminary ruling in the same procedure. Moreover, it postpones the possible issues which could arise because of different national treatment of the ECHR provisions (for example, constitutional rank in Austria and higher/lower status in the other Member States) in conjunction with Protocol 16 ECHR application. It avoids the conflicts in interpretation of the analogous ECHR and Charter provisions by the Strasburg and Luxembourg Courts - at least until a necessary legal environment for the use of Protocol No. 16 within EU legal order is created ${ }^{38}$.

It is quite probable that the accession will be delayed for an indefinite period of time - due to the likely impossibility of reaching a consensus on a new version of the Draft accession agreement with all members of the Council of Europe (such as Russia, Ukraine and Turkey) in the very near future. At the same time, European Union accession to the European Convention on Human Rights and Fundamental freedoms remains a legal duty in accordance with Art. 6 TEU, Protocol No. 8 to the TEU and to the TFEU, and a Declaration No. 2 on Article 6 (2) TEU. My presumption is that the EU may choose another tactics in the next round of the negotiations. These could include preparing the detailed description of internal implementing measures which take into account all points of critique raised by the Opinion, or perhaps creating the legal mechanisms for the implementation of Protocol No. 16 ECHR within EU Member States' legal systems. However, only time will show which direction the Luxemburg and Strasburg negotiators will take.

\footnotetext{
${ }^{38}$ See, for example, Stian Oby Johansen. "Some thoughts on the ECJ hearing on the Draft EU - ECHR Accession Agreement. Part 2 of 2" (Øby-kanalen, 7 May 2014) <https://obykanalen. wordpress.com/2014/05/07/some-thoughts-on-the-ecj-hearingon-the-draft-eu-echr-accession-agreement-part-2-of-2>; Thomas Streinz, "Forum Shopping between Luxembourg and Strasbourg?" (Verfassungsblog, 17 June 2014) < http://www.verfassungsblog. de/en/forum-shopping-zwischen-luxemburg-und-strassburg/\#. VP-wY3yG-NY>.
}

\section{REFERENCES}

Allan Rosas, "Constitutionalising the EU Judicial System: Essays in Honour of Pernilla Lindh" (Pascal Cardonnel, Allan Rosas, Nils Wahl ed., Bloomsbury Publishing, 2012) 106.

Christina Eckes, "EU Accession to the ECHR: Between Autonomy and Adaptation" (2013) 76 The Modern Law Review (Issue 2) 254 -285.

Elisa Morgera, "The External Environmental Policy of the European Union: EU and International Law Perspectives" (Cambridge University Press, 2012) 303.

Giuseppe Martinico, "Four Points on the Court of Justice of the EU. Perspectives on Federalism" (2014) 6 Perspectives on Federalism (Issue 3) 102-125 114.

Jean-Paul Jacqué, 'The Accession of the European Union to the European Convention on Human Rights and Fundamental Freedoms" (2011) 48 Common Market Law Review 95-1023 9951001.

Jörg Polakiewicz, "EU Law and the ECHR: Will EU Accession to the European Convention on Human Rights Square the Circle?" (SSRN, September 26, 2013) <http://ssrn.com/abstract=2331497> 12.

José Martín Pérez de Nanclares, "The accession of the European Union to the ECHR: More than just a legal issue" (2013) IDEIR working paper No. 15 <https://www.ucm.es/data/cont/docs/595-2013-11-07-the\%20accesion.pdf>. 
Leonard Besselink, "Acceding to the ECHR notwithstanding the Court of Justice Opinion 2/13" (Verfassungsblog, 23 December 2014), <http://www.verfassungsblog.de/en/acceding-echr-notwithstanding-court-justice-opinion-213/\#.VVyCTizDQ-Q>.

Paul Gragl, "A giant leap for European Human Rights? The Final Agreement on the European Union's accession to the European Convention on Human Rights" (2014) 51 Common Market Law Review (Issue 1) 13-58 16.

Paul Gragl, "Human Rights Law in Europe: The Influence, Overlaps and Contradictions of the EU and the ECHR" (Kanstantsin Dzehtsiarou, Theodore Konstadinides, Tobias Lock ed., Routledge Research in Human Rights Law) 37.

Roberto Baratta, "Accession of the EU to the ECHR: The rationale for the ECJ's prior involvement mechanism" (2013) 50 Common Market Law Review (Issue 5) 1305-1332 1311.

Stian Oby Johansen, "Some thoughts on the CJEU hearing on the Draft EU - ECHR Accession Agreement. Part 1 of 2" (Øbykanalen, 6 May 2014)<https://obykanalen.wordpress.com/2014/05/06/some-thoughts-on-the-ecj-hearing-on-the-draft-eu-echr-accessionagreement-part-1-of-2>.

Stian Oby Johansen. "Some thoughts on the ECJ hearing on the Draft EU — ECHR Accession Agreement. Part 2 of 2" (Øby-kanalen, 7 May 2014) <https://obykanalen.wordpress.com/2014/05/07/some-thoughts-on-the-ecj-hearing-on-the-draft-eu-echr-accessionagreement-part-2-of-2>.

Theodore Konstadinides and Noreen O'Meara, "EU Security and Justice Law: After Lisbon and Stockholm" (Diego Acosta Arcarazo, Cian Murphy ed, Bloomsbury Publishing, 2014) 82.

Thomas Streinz, "Forum Shopping between Luxembourg and Strasbourg?" (Verfassungsblog, 17 June 2014) <http://www. verfassungsblog.de/en/forum-shopping-zwischen-luxemburg-und-strassburg/\#.VP-wY3yG-NY>.

Tobias Lock, "The ECJ and the ECtHR: The Future Relationship between the Two European Courts" (2009) 8 Law and Practice of International Courts and Tribunals 375-398 376.

Tobias Lock, "Walking on a tightrope: the draft ECHR agreement and the autonomy of the EU legal order" (2011) 48 Common Market Law Review (Issue 4) 1025-1054 1025. 